\title{
The Synergistic Effect of Biosynthesized Silver Nanoparticles and Phage ZCSE2 as a Novel Approach to Combat Multidrug-Resistant Salmonella enterica
}

\author{
Abdallah S. Abdelsattar ${ }^{1,2,+}{ }^{+}$, Rana Nofal ${ }^{1,+}{ }^{+}$, Salsabil Makky ${ }^{1} \mathbb{D}$, Anan Safwat ${ }^{1} \mathbb{D}$, Amera Taha $^{1}$ and \\ Ayman El-Shibiny 1,3,*(D) \\ 1 Center for Microbiology and Phage Therapy, Zewail City of Science and Technology, Giza 12578, Egypt; \\ p-abdallah.abdelsattar@zewailcity.edu.eg (A.S.A.); p-rnofal@zewailcity.edu.eg (R.N.); \\ syoussef@zewailcity.edu.eg (S.M.); agaber@zewailcity.edu.eg (A.S.); s-ameraelsayed@zewailcity.edu.eg (A.T.) \\ 2 Center for X-ray and Determination of Structure of Matter, Zewail City of Science and Technology, \\ Giza 12578, Egypt \\ 3 Faculty of Environmental Agricultural Sciences, Arish University, Arish 45511, Egypt \\ * Correspondence: aelshibiny@zewailcity.edu.eg \\ + These authors contributed equally to this work.
}

check for updates

Citation: Abdelsattar, A.S.; Nofal, R.; Makky, S.; Safwat, A.; Taha, A.;

El-Shibiny, A. The Synergistic Effect of Biosynthesized Silver

Nanoparticles and Phage ZCSE2 as a

Novel Approach to Combat

Multidrug-Resistant Salmonella

enterica. Antibiotics 2021, 10, 678.

https://doi.org/10.3390/antibiotics 10060678

Academic Editors: Alan J. Hibbitts, Sofia A. Papadimitriou and Carlos M. Franco

Received: 31 March 2021

Accepted: 1 June 2021

Published: 5 June 2021

Publisher's Note: MDPI stays neutral with regard to jurisdictional claims in published maps and institutional affiliations.

\begin{abstract}
The emergence and evolution of antibiotic-resistant bacteria is considered a public health concern. Salmonella is one of the most common pathogens that cause high mortality and morbidity rates in humans, animals, and poultry annually. In this work, we developed a combination of silver nanoparticles (AgNPs) with bacteriophage (phage) as an antimicrobial agent to control microbial growth. The synthesized AgNPs with propolis were characterized by testing their color change from transparent to deep brown by transmission electron microscopy (TEM) and Fourier-Transform Infrared Spectroscopy (FTIR). The phage ZCSE2 was found to be stable when combined with AgNPs. Both minimum inhibitory concentration (MIC) and minimum bactericidal concentration (MBC) were evaluated for AgNPs, phage, and their combination. The results indicated that MIC and MBC values were equal to $23 \mu \mathrm{g} / \mathrm{mL}$ against Salmonella bacteria at a concentration of $10^{7} \mathrm{CFU} / \mathrm{mL}$. The combination of $0.4 \times$ MIC from AgNPs and phage with Multiplicity of Infection (MOI) 0.1 showed an inhibitory effect. This combination of AgNPs and phage offers a prospect of nanoparticles with significantly enhanced antibacterial properties and therapeutic performance.
\end{abstract}

Keywords: AgNPs; antibacterial; antimicrobial; antibiotic-resistant bacteria; green synthesis; phage therapy; green synthesis; synergetic effect; FTIR; time-killing curve

\section{Introduction}

Salmonella is one of the most common pathogens with transfer occuring from animal feces to food, soil, and water. It is considered the second most frequently reported pathogen that is associated with zoonosis. As a facultative anaerobic Gram-negative, non-spore-forming, and non-capsulated bacteria, Salmonella belongs to the Enterobacteriaceae family [1]. It is responsible for around 150,000 deaths annually. About 93 million cases are diagnosed yearly with salmonellosis, accompanied by symptoms of gastroenteritis, bacteremia, and enteric fever [2]. Antibiotics are still considered the first line of treatment of Salmonella infection, including ampicillin, amoxicillin, chloramphenicol, and trimethoprim-sulfamethoxazole. However, due to excessive use of antibiotics in therapeutic and industrial applications, multidrug-resistant (MRD) Salmonella is widely spread and transmitted from animals to humans [3]. Following the spread of antibiotic-resistant strains, alternatives are sought to limit the resulting medical and economic effects.

Phages are among the promising alternative to antibiotics. Virulent phages are viruses that infect bacterial cells, produce new virions, and obligatorily kill their hosts. Phages are the natural enemies of bacteria, without interfering with mammalian and human cells $[4,5]$. 
Their narrow host range enables their specific targeting of bacterial species or sub-strains in the same species, including Salmonella treatment [6,7]. Compared to antibiotics, phage isolation and laboratory preparation are time, effort, and cost-effective, yet further efforts are needed to transfer phage applications from laboratory bench to markets and to increase their shelf life [8-10]. However, the issue of bacterial resistance development towards phages could happen during the process of phage treatment [11-14]. Therefore, to improve phage efficiency, tolerance, and delivery, recent approaches support coupling phages with other bio-control agents such as antibiotics [15], natural products (e.g., venom, propolis, and extracted oils) [16], phage purified enzymes (e.g., lysins, endopeptidases, amidases, and transglycosylases) [17], in addition to syntactic compounds and nanoparticles [18-20].

Another approach is to use antibacterial compounds such as silver, which has been administrated before as an antimicrobial agent due to its efficiency against Gram-positive and Gram-negative bacteria [21,22]. AgNPs have growth inhibitory effects on various multidrug-resistant bacteria including Salmonella [23,24]. Similar to phages, the antimicrobial action of AgNPs relies on the recognition of the bacterial cell wall and membrane, bacterial penetration and damage through inducing the cellular toxicity and oxidative stress [25]. However, many studies have revealed various concerns regarding unpleasant side effects of AgNPs on human internal organs such as the lung, liver, and neurons [26,27]. Therefore, it is recommended to apply low concentrations of AgNPs to limit the side effects on human health and the environment. One common method is to use natural compounds such as an extract of propolis as a capping agent for AgNPs [28,29]. Propolis is produced by honeybees and is rich in flavonoids and phenolic acids [30]. In addition, it has many biological benefits including antimicrobial activity, antioxidant effect, in addition to its ability to improve the immune function $[31,32]$.

Few studies have investigated the effect of combining the two approaches: phages with metal nanoparticles. The previous findings were controversial since they reported that metal nanoparticles such as silver, gold, and copper oxide inactivate T4 phage, indicating that phages are not stable when combined with nanoparticles [33]. Another study suggested that AgNPs negatively affected a phage's life cycle because the nanoparticles interfere with the bacterial host cell and respectively might weaken the infectivity of phages [34]. Whereas, other studies introduced the combined approach, of C3 phage and gold nanoparticles (AuNPs), as a promising treatment for Pseudomonas aeruginosa planktonic and biofilm states, with high stability under a broad range of temperature, $\mathrm{pH}$, and salt concentration [35]. Moreover, other recent research work highlighted the high potential of green AuNPs and phage combination in eradicating the multi-drug resistant Staphylococcus aureus biofilms [36]. These data represent a gap in understanding the underlying of mechanism and effect of the phage-NPs combined approach.

Although both phages and AgNPs independently present interesting provisionary antibacterial implications, they have some limitations. Herein, we hypothesize that by mixing phage with AgNPs coated with propolis as a natural product, we can ascertain their bio-control capabilities with low doses of AgNPs and low incidences of resistance. Accordingly, this study amalgamates the activity of the previously isolated virulent phage ZCSE2 with a freshly-made and well-characterized AgNPs to investigate the possible synergetic effect in controlling the growth and spread of Salmonella. The mixture of phage ZCSE2 and AgNPs as a treatment will enhance our understanding of phage-nanoparticle stability and interactions, in addition to providing a potential bio-control agent for various applications.

\section{Results and Discussion}

\subsection{Characterization of AgNPs}

In this work, the bio-reduction of AgI ions to form the AgNPs was achieved successfully using the propolis extract presented as a bio-reducing agent. The AgNPs formation was confirmed by the color change of the transparent $\mathrm{AgNO}_{3}$ solution and propolis extraction into deep brown color after $5 \mathrm{~h}$ (Figure 1). AgNPs formation has also confirmed by the measurement of surface plasmon resonance in the resultant nanoparticles [37,38]. 
The various phytochemical compounds detected in the propolis extract (phenolic acids, flavonoids, and terpenoids) could be the reason behind the bio-reduction of the AgI ions and the capping with the formed AgNPs [39].

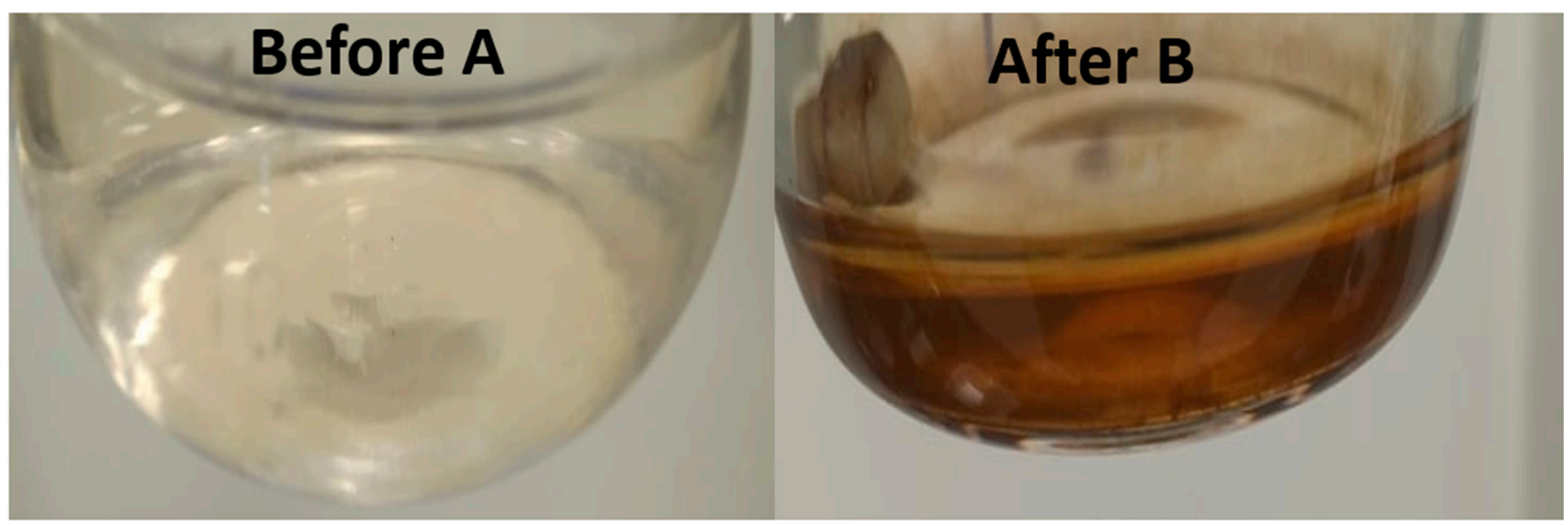

Figure 1. Flask A represents the color changes at time 0 (before) for $\mathrm{AgNO}_{3}$ and propolis extraction, while Flask $\mathrm{B}$ represents the biosynthesis of AgNPs following $5 \mathrm{~h}$ (after).

\subsection{The UV-Vis Spectrum}

The UV-Vis spectrum provided evidence of the formation of AgNPs prepared at $85^{\circ} \mathrm{C}$. The maximum absorption at 422 to $430 \mathrm{~nm}$ is an indication of surface plasmon resonance (Figure 2). By contrast, a single peak is visible at room temperature [40]. Bioreduction of $\mathrm{Ag}^{+}$through biomolecules found in the propolis could be the reason behind this observation [41]. In addition, the solution was diluted by using deionized water (Figure S6A). The resulting signal were time dependent (Figure S6B) and temperature dependent (Figure 2). The most optimal temperature, displaying a sharp peak at 422 to $430 \mathrm{~nm}$ was $85^{\circ} \mathrm{C}$, followed by $55^{\circ} \mathrm{C}$. However, the room temperature $\left(25^{\circ} \mathrm{C}\right)$ and above water boiling point $\left(115^{\circ} \mathrm{C}\right)$ preparations did not form nanoparticles. In previous work, the absorbance of biosynthesized AgNPs with propolis showed a similar wavelength peak from 324 to $449 \mathrm{~nm}$ and lower absorbance intensity $\sim 2.25$ a.u without dilution [29]. Another study supports $\lambda$ max of AgNPs, which is biosynthesized by propolis extraction at $424 \mathrm{~nm}[28]$.

\subsection{Visualization by TEM}

The morphology and size of the nanoparticles was examined by using TEM as shown in Figure 3. The micrographs showed that the biosynthesized AgNPs are oval in shape with a range of sizes from 2 to $41 \mathrm{~nm}$ in diameter, which is within the range of nanoparticles. Figure 3A represents the smart form of core-shell particles of AgNP and Figure 3B depicts the two different color intensities which indicate the capping process of AgNP with ethanolic extract of propolis [42]. This capping process is essential to control the size of AgNPs [43]. It enhances the antibacterial activity and biofilm clearance [44], provides bio-stability over the course of infection time [45], and most importantly it provides lower cytotoxicity effect [46]. It was clear that the AgNPs were bound to the capsid and tail fibers of the phage (Figure 4). This interaction will facilitate the delivery of nanoparticles during phage binding to specific bacterial receptors. 


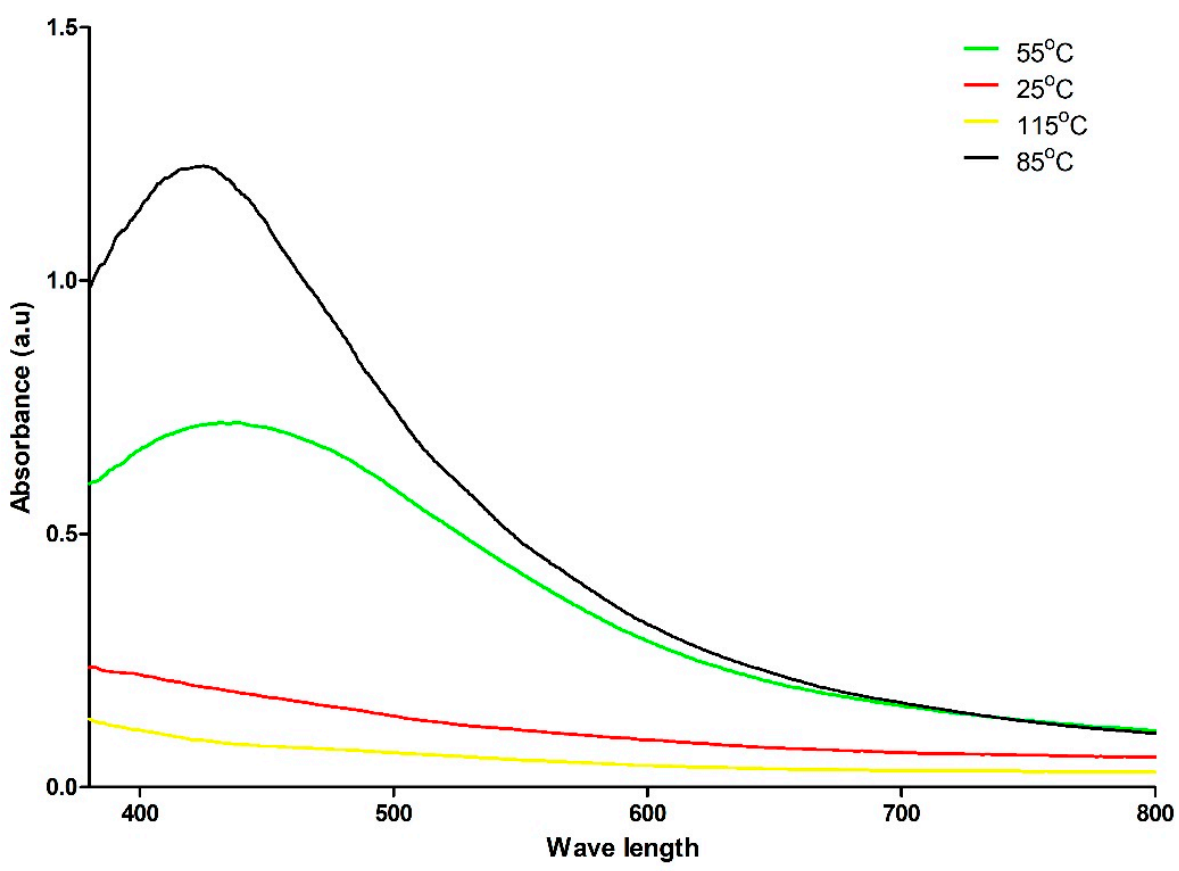

Figure 2. Shows the UV-Visible spectra of AgNPs coated by propolis extraction that were prepared at different temperatures.



Figure 3. Presents the different sizes of AgNPs. (A) core-shell particles of AgNP. (B) AgNP coated with ethanolic extract of propolis. The scale bar is $10 \mathrm{~nm}$. 


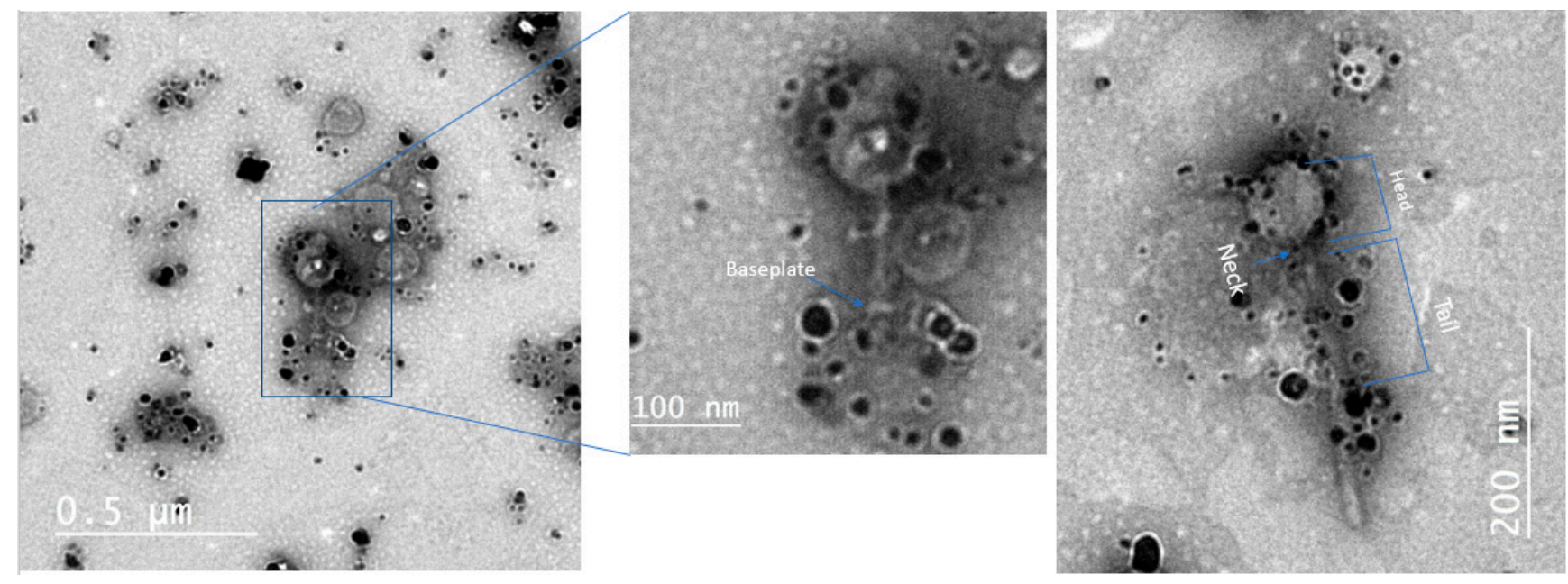

Figure 4. Shows the interaction between phage and biosynthesized AgNPs.

\subsection{Zeta Potential}

The zeta potential of the biosynthesized AgNPs displayed a sharp peak at $-22.2 \mathrm{mV}$ (Figure S4), which indicates that the surface of the AgNPs has a negative charge that is uniformly distributed in the solution. In addition, because of this negative charge the AgNPs showed that there was a high stability in the medium due to propolis extraction that electrostatically stabilized the biosynthesized AgNPs surfaces [47]. One of the important requirements to realize the use of AgNPs is to predict the interaction between nanoparticles and macromolecules in the body. For example, DNA carries a negative charge as AgNPs and this reduces the cytotoxicity of AgNPs in the cells [48]. Moreover, since most plasma proteins have a negative charge at physiological $\mathrm{pH}$, the negative charge of AgNPs will provide a low risk of the protein corona [49].

\subsection{FTIR Analysis}

FTIR is one of the significant tools used to identify the functional groups and the presence of organic compounds that bind to biosynthesized AgNPs surfaces. The FTIR spectrum obtained from AgNPs coated by propolis extraction (Figure S5) displayed the following peaks $3385 \mathrm{~cm}^{-1}$ (for hydroxyls [50]), $2996 \mathrm{~cm}^{-1}$ (for stretching vibration (O)CH3 that found in propolis components [51,52], $2894 \mathrm{~cm}^{-1}$ for the saturated $\mathrm{CH}$ stretches), $1644 \mathrm{~cm}^{-1}$ (bonds in carbonyls and carboxy [53]), $1387 \mathrm{~cm}^{-1}$ (heterocyclic compounds (C-O-C) which is in alkaloids and flavones [54]), $1226 \mathrm{~cm}^{-1}$ (C-O group in hydroxyflavonoids [55]), and $1193 \mathrm{~cm}^{-1}$ (methylene beside the carbonyl group [56]). The FTIR analysis implied that the biological molecules had been involved in capping and stabilizing AgNPs.

\subsection{Disc and Well Diffusion Methods}

The antibacterial effect of the AgNPs was tested against pathogenic $S$. Enteritidis WT (Platten). Direct spotting provides information on whether the concentration has an antibacterial effect or not. The diameters of the inhibitory zones of different concentrations of biosynthesized AgNPs were measured (Table 1). In our previous published work [6], the antibiotic sensitivity profile for the same strain was conducted and revealed that the bacterium is resistant to many antibiotics including Cefaclor $30 \mu \mathrm{g}$, Clarithromycin $15 \mu \mathrm{g}$, Erythromycin $15 \mu \mathrm{g}$, Vancomycin $30 \mu \mathrm{g}$, Linezolid $30 \mu \mathrm{g}$, and Novobiocin $30 \mu \mathrm{g}$ [6]. However, AgNPs displayed a higher efficiency to inhibit the growth of the bacterial culture. All experiments were performed in parallel with the use of propolis extract to confirm that antibacterial activity is due to the biosynthesized AgNPs (Figure S3). AgNO 3 solution had similar antibacterial activity to biosynthesized AgNPs against Salmonella bacteria when direct spotting, well, and disc diffusion methods are used (Table S2). $\mathrm{AgNO}_{3}$ is used as a supplier source of $\mathrm{Ag}^{+}$in the solution because it has antibacterial activity against bacteria 
due to its ability to bind to biomacromolecules such as DNA, RNA, proteins [57,58]. The antibacterial effect of AgNPs is due to the inner membrane damage without affecting the outer membrane and the accumulation of reactive oxygen species and intracellular $\mathrm{Ca}^{2+}[59]$.

Table 1. Zone of inhibition obtained though the direct spotting, disk and well diffusion tests.

\begin{tabular}{cccc}
\hline \multirow{2}{*}{ Serial Dilution } & & Dimeter (mm) & \\
\cline { 2 - 4 } & Direct Spotting & Disk Diffusion & Well Diffusion \\
\hline $3 \%$ and $1.5 \%$ Propolis extract & without antibacterial effect & 0 & 0 \\
\hline $184 \mu / \mathrm{mL}$ of AgNPs & antibacterial effect & 11 & 12 \\
\hline $92 \mu \mathrm{g} / \mathrm{mL}$ of AgNPs & antibacterial effect & 10 & 10 \\
\hline $46 \mu \mathrm{g} / \mathrm{mL}$ of AgNPs & antibacterial effect & 7 \\
\hline $23 \mu \mathrm{g} / \mathrm{mL}$ of AgNPs & antibacterial effect & 6 & 7 \\
\hline $11.5 \mu \mathrm{g} / \mathrm{mL}$ of AgNPs & without antibacterial effect & 8 & 6 \\
\hline
\end{tabular}

\subsection{Phage Stability}

The Salmonella phage ZCSE2 (MK673511) was characterized in order to determine its potential treatment to control the growth of Salmonella. The phage displayed high stability in different environmental conditions including $\mathrm{pH}$ and temperature [6]. To the best of our knowledge, no previous studies were conducted to investigate the stability of phage with biosynthesized AgNPs. This gap of information limits the possibility of combining phage therapy with antibacterial use of nanoparticles. Our results showed an in significant difference between the phage titer before and after incubation for $4 \mathrm{~h}$ with the $92 \mu \mathrm{g} / \mathrm{mL}$ of AgNPs at $37^{\circ} \mathrm{C}$ (Figure 5). Compared to other viruses including (H3N2) influenza virus [60] and the chikungunya virus [61], phage ZCSE2 showed a higher stability when combined with AgNPs. The titer of ZCSE2 with AgNPs was around $3.8 \times 10^{6} \mathrm{PFU} / \mathrm{mL}$ and the titer of phage alone was $2.1 \times 10^{6} \mathrm{PFU} / \mathrm{mL}$ after $4 \mathrm{~h}$ at $37^{\circ} \mathrm{C}$ without a significant difference $(p>0.05)$. This stability data cannot be generalized for all phage families since previous studies showed that high concentrations of AgNPs inactivated T4 phage [33]. Therefore, further work is needed to test the stabilities of different biosynthesized AgNPs on different phage families. Unfortunately, low-speed centrifugation and filtration can only remove some of the bacterial debris without reducing the lipopolysaccharides (LPS), peptidoglycan, and flagella [14] in addition to the different proteins that are produced as a result of bacterial burst after phage infection. This bacterial debris could interfere with AgNPs and affect their interaction with phage. For this reason, we used Bradford assay to predict the total proteins that may be produced and affect the phage/AgNPs interaction (supplementary data). Therefore, the phage stock was centrifugated at medium speed $\left(15,300 \times g\right.$ for $1 \mathrm{~h}$ at $\left.4^{\circ} \mathrm{C}\right)$ in order to reduce the amount of these proteins as much as possible by precipitating the phage and discarding the supernatant that contain most of these proteins.

\subsection{MIC and $M B C$}

As long as the concentration of AgNPs is higher than $23 \mu \mathrm{g} / \mathrm{mL}$, no bacterial growth was observed after $24 \mathrm{~h}$. Therefore, the minimum concentration of AgNPs that was able to inhibit the growth of $S$. Enteritidis WT (Platten) is $23 \mu \mathrm{g} / \mathrm{mL}$ and it is the same concentration that was needed to kill the bacteria. This concentration is higher than the concentration that was used by Shimaa et al. who reported that the values of both MIC and MBC were equal to $16 \mu \mathrm{g} / \mathrm{mL}$ when they used it against $S$. Enteritidis bacteria [62]. However, our reported concentration was significantly lower than the concentration used by Ragaa et al. who found that the MIC was $1 \mathrm{mg} / \mathrm{mL}$ against S. enterica subsp. salamae bacterium [63]. We also studied the synergistic effect of both phage ZCSE2 and AgNPs to inhibit the growth of $S$. Enteritidis WT (Platten). For instance, using $0.5 \times$ MIC AgNPs with different 
MOIs of ZCSE2 from 1 to 0.01 showed an inhibitory effect. To the best of our knowledge, this synergetic effect is the first to be reported and proposed a novel approach to control pathogenic bacteria. The applications of nanoparticles to control MRD bacteria opens the door for using it as an alternative to antibiotics. This study is the first to discuss the synergy between biosynthesized sub-lethal dose of AgNPs and phage. Stressing the bacteria under the effect of the sub-lethal dose of AgNPs enabled them to be lysed easily by phage [64] even at low concentrations. From the pharmacokinetic aspect, the high phage dosages will increase its possibility to be detected by the immune system and increase the chance of its clearance from the human/animal body [65]. By optimizing the combination between phage therapy and AgNPs, the dosses of both will be minimized and consequently limit the inflammatory immune responses.



Figure 5. Displays the phage stability against AgNPs after incubation for $4 \mathrm{~h}$.

\subsection{Time-Killing Curve}

An effective quantitative analysis was conducted to study the pharmacodynamics of AgNPs, in which the time-killing curves for bacteria were measured as a change in the optical density for $\lambda=600\left(\mathrm{OD}_{600}\right)$ [66]. At the first $360 \mathrm{~min}(6 \mathrm{~h})$, the curves showed that AgNPs $10 \mu \mathrm{g} / \mathrm{mL}$ had the lowest effect to reduce the bacterial growth, followed by the combination of AgNPs $10 \mu \mathrm{g} / \mathrm{mL}$ and ZCSE2 at MOI of 0.1, then AgNPs $23 \mu \mathrm{g} / \mathrm{mL}$, while the highest effect was observed with the treatment with ZCSE2 at MOI of 0.1. However, a secondary bacterial growth was observed after the first $6 \mathrm{~h}$ of infection with the treatment of phage alone due to bacterial resistance. On the other hand, phage ZCSE2 at MOI of 0.1 in combination with AgNPs $10 \mu \mathrm{g} / \mathrm{mL}$ were able to inhibit the bacterial growth after $930 \mathrm{~min}$ of the treatment (Figure 6). These results showed the significant difference between using phage alone and using it in combination with biosynthesized AgNPs. As a result, the data indicated that phage ZCSE2 alone at MOI 0.1 was able to reduce the bacterial intensity by 1.5 and $0.416 \mathrm{OD}_{600}$ compared to the control after 330 and $930 \mathrm{~min}(p<0.001)$, respectively. Nonetheless, the AgNPs alone reduced the bacterial growth by 0.691 and $0.527 \mathrm{OD}_{600}$ 
$(p<0.001)$ after 330 and $930 \mathrm{~min}$ of the experiment, respectively. On the other hand, the mixture of phage ZCSE2 at MOI 0.1 and $0.4 \times$ MIC of AgNPs displayed a reduction of 1.205 and $1.14 \mathrm{OD}_{600}$ compared to the control $(p<0.001)$ after 330 and $930 \mathrm{~min}$ of the experiment, respectively. The most interesting observation is that bacterial persistence occurs when the phage was used alone, while it was defeated when the phage was used in combination with AgNPs. Overall, there is a significant inhibitory effect when phage ZCSE2 at MOI of 0.1 combined with AgNPs in a sublethal concentration of $10 \mu \mathrm{g} / \mathrm{mL}$ in comparison to using AgNPs with the same concentration alone or the phage with the same MOI alone. Different experiments support these findings in supplementary data.



Figure 6. Illustrates the Time-Killing curve of S. Enteritidis WT (Platten) with $1 \times$ MBC of AgNPs, phage MOI 0.1, AgNPs of final concentration of $10 \mu \mathrm{g} / \mathrm{mL}$, and mixture of AgNPs of final concentration of $10 \mu \mathrm{g} / \mathrm{mL}$ and phage MOI 0.1 .

\section{Materials and Methods}

\subsection{Preparation of Propolis}

The propolis we used in this experiment was collected from the beehive and weighted as $0.5 \mathrm{~g}$ then grounded coarsely by mortar and pestle. The powder was suspended in $50 \mathrm{~mL}$ $80 \%$ ethanol then placed at $80^{\circ} \mathrm{C}$ for $4 \mathrm{~h}$ before we store the solution at $4{ }^{\circ} \mathrm{C}$ overnight. The solution was filtered through $0.45 \mu \mathrm{m}$ pore membranes filter (Steradisc, Kurabo Co., Ltd., Osaka, Japan) to remove any suspended particles then stored at $-20{ }^{\circ} \mathrm{C}$.

\subsection{Biosynthesis of AgNPs}

The process of biosynthesis of AgNPs was done by preparing $10 \mathrm{~mL}$ of $1 \mathrm{mM}$ silver nitrate (Techno pharmachem, India) using deionized water. Exactly, $8.5 \mathrm{mg}$ of silver nitrate was added to $10 \mathrm{~mL}$ of deionized water in a beaker and the beaker was covered without any exposure to the light. Exactly, $10 \mathrm{~mL}$ of $3 \%$ of pre-prepared propolis was added carefully to the silver nitrate solution. Then, the solution was left for $5 \mathrm{~h}$ on the hot plate with a 
magnetic stirrer at different temperatures $\left(25,55,85\right.$, and $\left.105^{\circ} \mathrm{C}\right)$ to form the nanoparticle. The nanoparticle formation was confirmed by color change (brown) as a first step.

\subsection{Characterization of $A g N P s$}

\subsubsection{UV-Vis Spectroscopy}

The formation of AgNPs coated by propolis was characterized by the spectrophotometer (Jenway 7200 visible spectrophotometer) in the range of 340-800 nm. The resulted nanoparticles were diluted 10 folds using deionized water then placed in the cuvette, and the spectrum was measured.

\subsubsection{FTIR Analysis}

To detect product formation as a result of the interaction among biomolecules found in the propolis and nano silver particles, the bonds were analyzed by the FTIR spectrum of the biosynthesized AgNPs (Agilent system Cary 630 FTIR model)in the range of $4000-400 \mathrm{~cm}^{-1}$ at room temperature, as previously described [67].

\subsubsection{TEM and Zeta Potential}

The size and shape of the biosynthesized AgNPs were investigated by using TEM at the National Research Center (Cairo, Egypt). The produced AgNPs were put on the copper grids and left to dry. Then, the sample was placed in TEM (JEOL 1230). The Image $\mathrm{J} 1.8 \mathrm{v}$ program was used to measure the sizes and perform the magnification. For the determination of the zeta potential of the AgNPs, Zetasizer (Nano ZS, Malvern, UK) was used and the raw data were analyzed by Zetasizer software. The results from Zetasizer were obtained after diluting the sample by 100 folds with deionized water. The zeta potential of AgNPs was examined at Nawah Scientific Company.

\subsection{Antibacterial Effect of AgNPs}

\subsubsection{Bacterial Culture}

This work was done on Salmonella Enteritidis WT (Platten) (S. Enteritidis) that is a gift from The University of Nottingham (United Kingdom). Stocks were maintained in 20\% $(v / v)$ glycerol at $-80^{\circ} \mathrm{C}$ until needed. Bacterial strains were grown on Tryptone Soya Agar (TSA; Oxoid, UK) overnight at $37^{\circ} \mathrm{C}$. The antibiotic sensitivity test was conducted on this bacterium before and the bacterium was found to be resistant to eight different classes of antibiotics "multidrug resistant bacterium" [6,68].

\subsubsection{MIC and MBC of AgNps}

To determine the MIC, a microbroth dilution method was conducted by following the procedure described by Prashik et al. [69] by evaluating the visible growth of $S$. Enteritidis in the Tryptone Soya Broth (TSB; Oxoid, UK) with some modifications. Briefly, S. Enteritidis was grown on TSA plates. Then, fresh colonies were harvested to be inoculated in the $\mathrm{TSB}$, which incubated overnight at $37^{\circ} \mathrm{C}$. Ten $\mu \mathrm{L}$ of bacteria was added to $90 \mu \mathrm{L}$ of clear TSB and AgNPs. The AgNPs was adjusted to be diluted by two folds in each well with different concentration from $92 \mu \mathrm{g} / \mathrm{mL}$ to $5.25 \mu \mathrm{g} / \mathrm{mL}$. After $24 \mathrm{~h}$ of incubation, the MIC was determined where the clear well with the lowest AgNPs concentration was observed. In each clear well, $10 \mu \mathrm{L}$ of TSB was withdrawn and added to fresh liquid media and incubated for another $24 \mathrm{~h}$. After the incubation, the clear well with the lowest concentration of AgNPs was considered as MBC.

\subsubsection{Antibacterial Effect of AgNPs Using Disk and Well Diffusion and Direct Spotting}

The antibacterial effect of the AgNPs on Salmonella was determined by three different methods. First, to predict if the AgNPs have antibacterial activity, direct spotting was used according to Baldi et al. [70]. Briefly, different concentrations of AgNPs and $\mathrm{AgNO}_{3}$ $(184 \mu \mathrm{g} / \mathrm{mL}, 92 \mu \mathrm{g} / \mathrm{mL}, 46 \mu \mathrm{g} / \mathrm{mL}, 23 \mu \mathrm{g} / \mathrm{mL}, 11.5 \mu \mathrm{g} / \mathrm{mL}, 5.75 \mu \mathrm{g} / \mathrm{mL})$ were prepared and directly spotted on an overlay of $S$. Enteritidis on TSA plate. The second method 
that was used is disc diffusion according to Ajitha et al. with slight modifications [71]. Briefly, a day culture of the bacteria was prepared by adding a single colony to $500 \mu \mathrm{L}$ TSB and incubated at $37^{\circ} \mathrm{C}$ for $2 \mathrm{~h}$. Then, the bacterial culture was swapped on TSA plates and sterile disks were added directly on the surface of TSA plates that have the bacterial culture. Then, the serial dilutions of NPs $10 \mu \mathrm{L}$ were spotted on the disks. The third method that was used is the well diffusion method according to Gavade et al. [31]. Briefly, different wells were formed in TSA plates that have the bacterial culture, then $20 \mu \mathrm{L}$ of different concentrations of AgNPs and $\mathrm{AgNO}_{3}$ were added. Propolis at two different concentrations ( $3 \%$ and $1.5 \%$ ) were also used throughout the experiment as a negative control. The inhibition zones were assessed by measuring the diameters of the areas that show no bacterial growth.

\subsection{Phage Combination with AgNPs}

\subsubsection{Phage Stability with AgNPs}

The Myoviridae phage ZCSE2 with ID MK673511 was used in combination with AgNPs to investigate possible synergetic effects. To examine the stability of phage ZCSE2, we added $100 \mu \mathrm{L}$ of phage at $10^{6} \mathrm{PFU} / \mathrm{mL}$ to an Eppendorf containing $100 \mu \mathrm{L}$ of AgNPs $(184 \mu \mathrm{g} / \mathrm{mL})$ to reach to $92 \mu \mathrm{g} / \mathrm{mL}$ of AgNPs as a final concentration and incubated it for four hours at $37^{\circ} \mathrm{C}$ in shaking incubator. The phage titer was determined before and after incubation to test its stability by double-agar overlay plaque assays [32]. Briefly, $100 \mu \mathrm{L}$ of the bacterial culture was added to $4 \mathrm{~mL}$ of molten $0.7 \%$ (Bacto) top agar $\left(\approx 55^{\circ} \mathrm{C}\right)$, and poured on the top of TSA plates. After $15 \mathrm{~min}, 10 \mu \mathrm{L}$ of 10 -fold serial-diluted phage and phage mixed with biosynthesis AgNPs were spotted on the bacterial lawn. The plates were left until the spots were dried and incubated upside down overnight at $37^{\circ} \mathrm{C}$.

\subsubsection{MIC for Phage and AgNPs}

The MIC was conducted as described above with different phage titers from $10^{6} \mathrm{PFU} / \mathrm{mL}$ to lower than $10^{1} \mathrm{PFU}$ with $0.5 \times$ MIC of AgNPs and in another experiment without AgNPs to measure the MIC for the phage alone. The bacterial initial concentration to measure the MIC was $1.5 \times 10^{7} \mathrm{CFU} / \mathrm{mL}$ to achieve a wide range of MOIs, from 0.1 to 0.000001 .

\subsubsection{In Vitro Time-Kill Assay}

A cuvette containing $1 \mathrm{~mL}$ of $S$. Enteritidis in TSB at $0.35 \mathrm{OD}_{600}$ was used as a positive control. Another four cuvettes; one containing the bacteria with the phage at MOI of 0.1 , one containing the bacteria and AgNPs with final concentration of $10 \mu \mathrm{g} / \mathrm{mL}$, one containing the bacteria and AgNPs with final concentration of $23 \mu \mathrm{g} / \mathrm{mL}$, and the last one containing phage ZCSE2 MOI 0.1, AgNPs with final concentration of $10 \mu \mathrm{g} / \mathrm{mL}$ and bacteria were used. In addition, a negative control (fresh TSB without bacterial growth) was used as a blank at the time point zero. All cuvettes were incubated at $37^{\circ} \mathrm{C}$ with gentle shaking for $930 \mathrm{~min}$. During the incubation period the samples were analyzed by measuring the $\mathrm{OD}_{600}$ at defined time points $(0,30,60,90,150,180,210,240,300,330,390$, $450,540,600,720$, and $930 \mathrm{~min}$ ).

\section{Conclusions}

This study provides a novel approach by using a combination of phage and nanoparticles as an alternative to antibiotics to get the maximum synergistic effect to control pathogenic bacteria. The biosynthesized AgNPs were produced from silver nitrate and propolis extract, in which they were characterized through a color change, UV-Vis spectrum, Zeta potential, FTIR, and TEM. The antibacterial effect of AgNPs alone and in combination with ZCSE2 against Salmonella was evaluated by measuring MIC, MBC, timekilling curve, bacterial survival and reduction. The data showed that the combination of AgNPs and phage ZCSE2 reduced the bacterial growth significantly in comparison with other treatments and this was clear when the bacterial turbidity after $15.5 \mathrm{~h}$ showed a high reduction in $\mathrm{OD}_{600}$ for the treatment of both phage and AgNPs in comparison to the 
phage treatment. Our results suggest that the combination of phage and nanoparticles has a potential for phage applications to control bacterial infections.

Supplementary Materials: The following are available online at https:/ /www.mdpi.com/article/10 .3390 /antibiotics10060678/s1, Figure S1: Shows the effect of using ZCSE2, AgNPs, and the mixture of both of them on bacterial growth, Figure S2: Shows Time-Killing curve of S. Enteritidis with phage at MOI 0.03, AgNPs of final concentration of $10 \mu \mathrm{g} / \mathrm{mL}$, and mixture of AgNPs of final concentration of $10 \mu \mathrm{g} / \mathrm{mL}$ and phage MOI 0.03, Figure S3: Shows the comparison between the inhibition zone of AgNPs in disc diffusion, Figure S4: Shows the zeta potential distribution for biosynthesized AgNPs with a single peak at $22.2 \mathrm{mV}$, Figure S5: Represents FTIR spectrum of biosynthesized AgNPs, Table S1: Shows the values of released proteins after using AgNPs, phage, and the combination of both of them, Table S2: Shows the inhibition zones resulting from direct spotting, disk and well diffusion tests for $\mathrm{AgNO}_{3}$ solution.

Author Contributions: Conceptualization, A.S.A. and R.N.; methodology, A.T., A.S., and S.M.; validation, R.N., A.S.A.; formal analysis, A.S.A.; writing-original draft preparation, R.N., S.M.; supervision, A.E.-S.; funding acquisition, A.E.-S. All authors have read and agreed to the published version of the manuscript.

Funding: This research was funded by Academy of Scientific Research and Technology (ASRT), Genetic call (51/2020) and Zewail City of Science and Technology internal grant No. ZC 019-2019.

Acknowledgments: We would like to thank Mohamed S. Fayez for his kind help and Nawah Scientific center, Almokattam, Cairo, Egypt, for helping in AgNPs characterization. The authors thank Fareed Aboul-ela for the critical evaluation of the manuscript's English language.

Conflicts of Interest: The authors declare no conflict of interest.

\section{References}

1. Fashae, K.; Ogunsola, F.; Aarestrup, F.M.; Hendriksen, R.S. Antimicrobial susceptibility and serovars of Salmonella from chickens and humans in Ibadan, Nigeria. J. Infect. Dev. Ctries. 2010, 4, 484-494. [CrossRef]

2. Majowicz, S.E.; Musto, J.; Scallan, E.; Angulo, F.J.; Kirk, M.; O’Brien, S.J.; Jones, T.F.; Fazil, A.; Hoekstra, R.M. The global burden of nontyphoidal salmonella gastroenteritis. Clin. Infect. Dis. 2010, 50, 882-889. [CrossRef]

3. Hyeon, J.Y.; Chon, J.W.; Hwang, I.G.; Kwak, H.S.; Kim, M.S.; Kim, S.K.; Choi, I.S.; Song, C.S.; Park, C.; Seo, K.H. Prevalence, antibiotic resistance, and molecular characterization of Salmonella serovars in retail meat products. J. Food Prot. 2011, 74, 161-166. [CrossRef]

4. Abedon, S.T.; Kuhl, S.J.; Blasdel, B.G.; Kutter, E.M. Phage treatment of human infections. Bacteriophage 2011, 1, 66-85. [CrossRef]

5. Garvey, M. Bacteriophages and the one health approach to combat multidrug resistance: Is this the way? Antibiotics 2020, 9, 414 . [CrossRef]

6. Mohamed, A.; Taha, O.; El-Sherif, H.M.; Connerton, P.L.; Hooton, S.P.T.; Bassim, N.D.; Connerton, I.F.; El-Shibiny, A. Bacteriophage ZCSE2 is a Potent Antimicrobial against Salmonella enterica Serovars: Ultrastructure, genomics and efficacy. Viruses 2020, $12,424$. [CrossRef]

7. El-Shibiny, A.; Dawoud, A. Bacteriophage applications for food safety. In Biocommunication of Phages; Witzany, G., Ed.; Springer: Cham, Switzerland, 2020; pp. 463-484, ISBN 9783030458850.

8. Yosef, I.; Goren, M.G.; Globus, R.; Molshanski-Mor, S.; Qimron, U. Extending the Host Range of Bacteriophage Particles for DNA Transduction. Mol. Cell 2017, 66, 721-728.e3. [CrossRef]

9. Seijsing, J.; Sobieraj, A.M.; Keller, N.; Shen, Y.; Zinkernagel, A.S.; Loessner, M.J.; Schmelcher, M. Improved Biodistribution and Extended Serum Half-Life of a Bacteriophage Endolysin by Albumin Binding Domain Fusion. Front. Microbiol. 2018, 9, 2927. [CrossRef]

10. Chanishvili, N. Bacteriophages as Therapeutic and Prophylactic Means: Summary of the Soviet and Post Soviet Experiences. Curr. Drug Deliv. 2016. [CrossRef]

11. Luong, T.; Salabarria, A.C.; Roach, D.R. Phage Therapy in the Resistance Era: Where Do We Stand and Where Are We Going? Clin. Ther. 2020, 42, 1659-1680. [CrossRef]

12. Oechslin, F. Resistance development to bacteriophages occurring during bacteriophage therapy. Viruses 2018, 10, 351. [CrossRef]

13. Burmeister, A.R.; Fortier, A.; Roush, C.; Lessing, A.J.; Bender, R.G.; Barahman, R.; Grant, R.; Chan, B.K.; Turner, P.E. Pleiotropy complicates a trade-off between phage resistance and antibiotic resistance. Proc. Natl. Acad. Sci. USA 2020, 117, 11207-11216. [CrossRef]

14. Abdelsattar, A.S.; Dawoud, A.; Makky, S.; Nofal, R.; Aziz, R.K.; El-Shibiny, A. Bacteriophages: From isolation to application. Curr. Pharm. Biotechnol. 2021. [CrossRef] 
15. Rodriguez-Gonzalez, R.A.; Leung, C.Y.; Chan, B.K.; Turner, P.E.; Weitz, J.S. Quantitative Models of Phage-Antibiotic Combination Therapy. mSystems 2020, 5. [CrossRef]

16. Cooper, C.J.; Koonjan, S.; Nilsson, A.S. Enhancing whole phage therapy and their derived antimicrobial enzymes through complex formulation. Pharmaceuticals 2018, 11, 34. [CrossRef]

17. Abdelrahman, F.; Easwaran, M.; Daramola, O.I.; Ragab, S.; Lynch, S.; Oduselu, T.J.; Khan, F.M.; Ayobami, A.; Adnan, F.; Torrents, E.; et al. Phage-Encoded Endolysins. Antibiotics 2021, 10, 124. [CrossRef]

18. Abdelsattar, A.S.; Abdelrahman, F.; Dawoud, A.; Connerton, I.F.; El-Shibiny, A. Encapsulation of E. coli phage ZCEC5 in chitosan-alginate beads as a delivery system in phage therapy. AMB Express 2019, 9, 87. [CrossRef]

19. Sunderland, K.S.; Yang, M.; Mao, C. Phage-Enabled Nanomedicine: From Probes to Therapeutics in Precision Medicine. Angew. Chem. Int. Ed. 2017, 56, 1964-1992. [CrossRef]

20. Hyman, P.; Denyes, J. Bacteriophages in Nanotechnology: History and Future. In Bacteriophages: Biology, Technology, Therapy; Springer International Publishing: Berlin/Heidelberg, Germany, 2018; pp. 1-31, ISBN 9783319405988.

21. Bae, E.; Park, H.-J.; Lee, J.; Kim, Y.; Yoon, J.; Park, K.; Choi, K.; Yi, J. Bacterial cytotoxicity of the silver nanoparticle related to physicochemical metrics and agglomeration properties. Environ. Toxicol. Chem. 2010, 29, 2154-2160. [CrossRef]

22. Silver, S.; Phung, L.T.; Silver, G. Silver as biocides in burn and wound dressings and bacterial resistance to silver compounds. J. Ind. Microbiol. Biotechnol. 2006, 33, 627-634. [CrossRef]

23. Su, H.L.; Lin, S.H.; Wei, J.C.; Pao, I.C.; Chiao, S.H.; Huang, C.C.; Lin, S.Z.; Lin, J.J. Novel nanohybrids of silver particles on clay platelets for inhibiting silver-resistant bacteria. PLoS ONE 2011, 6. [CrossRef] [PubMed]

24. Lara, H.H.; Ayala-Núñez, N.V.; del Turrent, L.C.I.; Padilla, C.R. Bactericidal effect of silver nanoparticles against multidrugresistant bacteria. World J. Microbiol. Biotechnol. 2010, 26, 615-621. [CrossRef]

25. Dakal, T.C.; Kumar, A.; Majumdar, R.S.; Yadav, V. Mechanistic basis of antimicrobial actions of silver nanoparticles. Front. Microbiol. 2016, 7, 1831. [CrossRef] [PubMed]

26. Hussain, S.M.; Hess, K.L.; Gearhart, J.M.; Geiss, K.T.; Schlager, J.J. In vitro toxicity of nanoparticles in BRL 3A rat liver cells. Toxicol. In Vitro 2005, 19, 975-983. [CrossRef]

27. Lam, C.W.; James, J.T.; McCluskey, R.; Hunter, R.L. Pulmonary toxicity of single-wall carbon nanotubes in mice 7 and 90 days after intractracheal instillation. Toxicol. Sci. 2004, 77, 126-134. [CrossRef] [PubMed]

28. Kischkel, B.; de Castilho, P.F.; de Oliveira, K.M.P.; Rezende, P.S.T.; Bruschi, M.L.; Svidzinski, T.I.E.; Negri, M. Silver nanoparticles stabilized with propolis show reduced toxicity and potential activity against fungal infections. Future Microbiol. 2020, 15, 521-539. [CrossRef]

29. Ghramh, H.A.; Khan, K.A.; Ibrahim, E.H.; Ansari, M.J. Biogenic synthesis of silver nanoparticles using propolis extract, their characterization, and biological activities. Sci. Adv. Mater. 2019, 11, 876-883. [CrossRef]

30. Castaldo, S.; Capasso, F. Propolis, an old remedy used in modern medicine. Fitoterapia 2002, 73, S1-S6. [CrossRef]

31. Ramadan, A.; Soliman, G.; Mahmoud, S.S.; Nofal, S.M.; Abdel-Rahman, R.F. Evaluation of the safety and antioxidant activities of Crocus sativus and Propolis ethanolic extracts. J. Saudi Chem. Soc. 2012, 16, 13-21. [CrossRef]

32. Gao, W.; Wu, J.; Wei, J.; Pu, L.; Guo, C.; Yang, J.; Yang, M.; Luo, H. Brazilian green propolis improves immune function in aged mice. J. Clin. Biochem. Nutr. 2014, 55, 7-10. [CrossRef]

33. Shimabuku, Q.L.; Ueda-Nakamura, T.; Bergamasco, R.; Fagundes-Klen, M.R. Chick-Watson kinetics of virus inactivation with granular activated carbon modified with silver nanoparticles and/or copper oxide. Process Saf. Environ. Prot. 2018, 117, 33-42. [CrossRef]

34. Gilcrease, E.; Williams, R.; Goel, R. Evaluating the effect of silver nanoparticles on bacteriophage lytic infection cycle-a mechanistic understanding. Water Res. 2020, 181, 115900. [CrossRef]

35. Ahiwale, S.S.; Bankar, A.V.; Tagunde, S.; Kapadnis, B.P. A Bacteriophage Mediated Gold Nanoparticles Synthesis and Their Anti-biofilm Activity. Indian J. Microbiol. 2017, 57, 188-194. [CrossRef]

36. Manoharadas, S.; Altaf, M.; Alrefaei, A.F.; Devasia, R.M.; Badjah Hadj, A.Y.M.; Abuhasil, M.S.A. Concerted dispersion of Staphylococcus aureus biofilm by bacteriophage and "green synthesized" silver nanoparticles. RSC Adv. 2021, 11, 1420-1429. [CrossRef]

37. Jafari, A.; Vaghari, H.; Jafarizadeh-Malmiri, H. Development of Antimicrobial Films Based on Aloe vera and Fabricated AgNPs Using Propolis. Proc. Natl. Acad. Sci. USA India Sect. B Biol. Sci. 2020, 91, 95-103. [CrossRef]

38. Mohammadlou, M.; Maghsoudi, H.; Jafarizadeh-Malmiri, H. A review on green silver nanoparticles based on plants: Synthesis, potential applications and eco-friendly approach. Int. Food Res. J. 2016, 23, 446-463.

39. Przybyłek, I.; Karpiński, T.M. Antibacterial properties of propolis. Molecules 2019, 24, 2047. [CrossRef]

40. Sharma, G.; Nam, J.-S.; Sharma, A.R.; Lee, S.-S. Antimicrobial potential of silver nanoparticles synthesized using medicinal herb coptidis rhizome. Molecules 2018, 23, 2268. [CrossRef]

41. Jagtap, U.B.; Bapat, V.A. Green synthesis of silver nanoparticles using Artocarpus heterophyllus Lam. seed extract and its antibacterial activity. Ind. Crops Prod. 2013, 46, 132-137. [CrossRef]

42. Ballauff, M.; Lu, Y. "Smart" nanoparticles: Preparation, characterization and applications. Polymer 2007, 48, 1815-1823. [CrossRef]

43. Ajitha, B.; Reddy, Y.A.K.; Reddy, P.S.; Jeon, H.-J.; Ahn, C.W. Role of capping agents in controlling silver nanoparticles size, antibacterial activity and potential application as optical hydrogen peroxide sensor. RSC Adv. 2016, 6, 36171-36179. [CrossRef] 
44. Niska, K.; Knap, N.; Kędzia, A.; Jaskiewicz, M.; Kamysz, W.; Inkielewicz-Stepniak, I. Capping agent-dependent toxicity and antimicrobial activity of silver nanoparticles: An in vitro study. Concerns about potential application in dental practice. Int. J. Med. Sci. 2016, 13, 772. [CrossRef] [PubMed]

45. Khan, F.; Iqbal, S.; Khalid, N.; Hussain, I.; Hussain, Z.; Szmigielski, R.; Janjua, H.A. Screening and stability testing of commercially applicable Heliotropium crispum silver nanoparticle formulation with control over aging and biostability. Appl. Nanosci. 2020, 10, 1941-1956. [CrossRef]

46. Thiyagarajan, K.; Bharti, V.K.; Tyagi, S.; Tyagi, P.K.; Ahuja, A.; Kumar, K.; Raj, T.; Kumar, B. Synthesis of non-toxic, biocompatible, and colloidal stable silver nanoparticle using egg-white protein as capping and reducing agents for sustainable antibacterial application. RSC Adv. 2018, 8, 23213-23229. [CrossRef]

47. Ardani, H.K.; Imawan, C.; Handayani, W.; Djuhana, D.; Harmoko, A.; Fauzia, V. Enhancement of the stability of silver nanoparticles synthesized using aqueous extract of Diospyros discolor Willd. leaves using polyvinyl alcohol. In Proceedings of the IOP Conference Series: Materials Science and Engineering, Busan, Korea, 26-28 August 2017; IOP Publishing: Bristol, UK, 2017; Volume 188, p. 12056.

48. Abdelsattar, A.S.; Dawoud, A.; Helal, M.A. Interaction of nanoparticles with biological macromolecules: A review of molecular docking studies. Nanotoxicology 2020, 15, 1-30.

49. Ahsan, S.M.; Rao, C.M.; Ahmad, M.F. Nanoparticle-protein interaction: The significance and role of protein corona. Cell. Mol. Toxicol. Nanopart. 2018, 1048, 175-198.

50. Peng, S.; McMahon, J.M.; Schatz, G.C.; Gray, S.K.; Sun, Y. Reversing the size-dependence of surface plasmon resonances. Proc. Natl. Acad. Sci. USA 2010, 107, 14530-14534. [CrossRef] [PubMed]

51. Jitian, S.; Bratu, I. Determination of optical constants of polymethyl methacrylate films from IR reflection-absorption spectra. In Proceedings of the AIP Conference Proceedings 1425, Timisoara, Romania, 16-18 April 2018; American Institute of Physics: College Park, MD, USA, 2018; Volume 2012, pp. 26-29.

52. Markham, K.R.; Mitchell, K.A.; Wilkins, A.L.; Daldy, J.A.; Lu, Y. HPLC and GC-MS identification of the major organic constituents in New Zeland propolis. Phytochemistry 1996, 42, 205-211. [CrossRef]

53. Rastogi, L.; Arunachalam, J. Sunlight based irradiation strategy for rapid green synthesis of highly stable silver nanoparticles using aqueous garlic (Allium sativum) extract and their antibacterial potential. Mater. Chem. Phys. 2011, 129, 558-563. [CrossRef]

54. Shameli, K.; Ahmad, M.B.; Zamanian, A.; Sangpour, P.; Shabanzadeh, P.; Abdollahi, Y.; Zargar, M. Green biosynthesis of silver nanoparticles using Curcuma longa tuber powder. Int. J. Nanomed. 2012, 7, 5603. [CrossRef]

55. Corciova, A.; Mircea, C.; Burlec, A.-F.; Cioanca, O.; Tuchilus, C.; Fifere, A.; Lungoci, A.-L.; Marangoci, N.; Hancianu, M. Antioxidant, antimicrobial and photocatalytic activities of silver nanoparticles obtained by bee propolis extract assisted biosynthesis. Farmacia 2019, 67, 482-489. [CrossRef]

56. Yu, J.; Wu, P. Crystallization process of poly ( $\varepsilon$-caprolactone)-poly (ethylene oxide)-poly ( $\varepsilon$-caprolactone) investigated by infrared and two-dimensional infrared correlation spectroscopy. Polymer 2007, 48, 3477-3485. [CrossRef]

57. Chen, J.; Li, S.; Luo, J.; Wang, R.; Ding, W. Enhancement of the antibacterial activity of silver nanoparticles against phytopathogenic bacterium Ralstonia solanacearum by stabilization. J. Nanomater. 2016. [CrossRef]

58. Randall, C.P.; Oyama, L.B.; Bostock, J.M.; Chopra, I.; O'Neill, A.J. The silver cation ( $\left.\mathrm{Ag}^{+}\right)$: Antistaphylococcal activity, mode of action and resistance studies. J. Antimicrob. Chemother. 2013, 68, 131-138. [CrossRef] [PubMed]

59. Seong, M.; Lee, D.G. Silver nanoparticles against Salmonella enterica serotype typhimurium: Role of inner membrane dysfunction. Curr. Microbiol. 2017, 74, 661-670. [CrossRef]

60. Xiang, D.; Zheng, Y.; Duan, W.; Li, X.; Yin, J.; Shigdar, S.; O'Connor, M.L.; Marappan, M.; Zhao, X.; Miao, Y. Inhibition of A/Human/Hubei/3/2005 (H3N2) influenza virus infection by silver nanoparticles in vitro and in vivo. Int. J. Nanomed. 2013, 8 , 4103. [CrossRef]

61. Sharma, V.; Kaushik, S.; Pandit, P.; Dhull, D.; Yadav, J.P.; Kaushik, S. Green synthesis of silver nanoparticles from medicinal plants and evaluation of their antiviral potential against chikungunya virus. Appl. Microbiol. Biotechnol. 2019, 103, 881-891. [CrossRef]

62. Omara, S.T.; Zawrah, M.F.; Samy, A.A. Minimum bactericidal concentration of chemically synthesized silver nanoparticles against pathogenic Salmonella and Shigella strains isolated from layer poultry farms. J. Appl. Pharm. Sci. 2017, 7, $214-221$.

63. Hamouda, R.A.; Yousuf, W.E.; Abdeen, E.E.; Mohamed, A. Biological and chemical synthesis of silver nanoparticles: Characterization, MIC and antibacterial activity against pathogenic bacteria. J. Chem. Pharm. Res 2019, 11, 1-12.

64. Comeau, A.M.; Tétart, F.; Trojet, S.N.; Prere, M.-F.; Krisch, H.M. Phage-antibiotic synergy (PAS): $\beta$-lactam and quinolone antibiotics stimulate virulent phage growth. PLoS ONE 2007, 2, e799. [CrossRef]

65. Cooper, C.J.; Khan Mirzaei, M.; Nilsson, A.S. Adapting drug approval pathways for bacteriophage-based therapeutics. Front. Microbiol. 2016, 7, 1209. [CrossRef]

66. Liu, Y.-Q.; Zhang, Y.-Z.; Sun, C.-Y.; Gao, P.-J. A novel approach to estimate in vitro antibacterial potency of Chinese medicine using a concentration-killing curve method. Am. J. Chin. Med. 2005, 33, 671-682. [CrossRef]

67. Baker, M.J.; Trevisan, J.; Bassan, P.; Bhargava, R.; Butler, H.J.; Dorling, K.M.; Fielden, P.R.; Fogarty, S.W.; Fullwood, N.J.; Heys, K.A.; et al. Using Fourier transform IR spectroscopy to analyze biological materials. Nat. Protoc. 2014, 9, 1771-1791. [CrossRef]

68. Hooton, S.P.T.; Atterbury, R.J.; Connerton, I.F. Application of a bacteriophage cocktail to reduce Salmonella Typhimurium U288 contamination on pig skin. Int. J. Food Microbiol. 2011, 151, 157-163. [CrossRef] 
69. Parvekar, P.; Palaskar, J.; Metgud, S.; Maria, R.; Dutta, S. The minimum inhibitory concentration (MIC) and minimum bactericidal concentration (MBC) of silver nanoparticles against Staphylococcus aureus. Biomater. Investig. Dent. 2020, 7, 105-109. [CrossRef]

70. Baldi, F.; Daniele, S.; Gallo, M.; Paganelli, S.; Battistel, D.; Piccolo, O.; Faleri, C.; Puglia, A.M.; Gallo, G. Polysaccharide-based silver nanoparticles synthesized by Klebsiella oxytoca DSM 29614 cause DNA fragmentation in E. coli cells. BioMetals 2016, 29, 321-331. [CrossRef]

71. Ajitha, B.; Reddy, Y.A.K.; Shameer, S.; Rajesh, K.M.; Suneetha, Y.; Reddy, P.S. Lantana camara leaf extract mediated silver nanoparticles: Antibacterial, green catalyst. J. Photochem. Photobiol. B Biol. 2015, 149, 84-92. [CrossRef] 